\title{
فعالية برنامج تلدريبى قائم على الوسائط المتعددة لتحسين مهارات التواصل لدى أطفال التوحد
}

\author{
! عراد \\ الباحثة / زينب محمد على عرفان
}

$$
\text { إشرافـ }
$$

الأستاذ الدكتور / جمال عطية فايد

أستاذ الصحت النفسيت (التربيتالخاصتة)

كليتالتربيت للطفولت المبكرة

جامعت المنصورة

$$
\begin{aligned}
& \text { المجلت العلميت لكليت رياض الأطفال ـ جامعت المنصورة } \\
& \text { المجلد السادس ـ العدد الأول } \\
& \text { يوليو 19. }
\end{aligned}
$$




\section{فعالية برنامج تدريبى قائم على الوسائط التعددة لتحسيز مهارات التواصل لدى أطفال التوحد}

* أرينب محمد على عرفان

مقدمة

تتمنتل احدى مؤشر ات حضـارة الأمم وارتقائها فى مدى عنايتهـــا بتربيـــة الأجيال بمختلف فئاتها، ويتجلى ذللك بوضوح فى مدى ما توليه للأطفال بـشكل عام ولذوى الاحتياجات الخاصة منهم بشكل خاص من عناية و اهتمام، وتــوفير امكانات النمو الثشامل لهم من كافة الجو انب مما يـسـاعد فــى اعــدادهم لحيــاة شخصية و اجتماعية مقبولة فى المجتمع بشكل عام. ويعد اضطر اب التوحد من الاضطر ابات التى ماز ال يدور حولها كثيــر

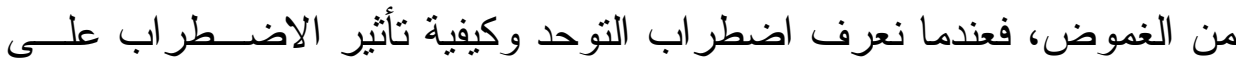
حياة الفرد، فإن ذلك يسهل علينا التعامل معهه ووضع الخطط العلاجية و التدريب، مما يجعل الفرد عضو ا فاعلا فى مجتمعه. مشكلة الدر اسة

ان التو اصل أمر ضرورى للبقاء الاجتماعى وخصيصـا فـى المجتمعــات الحديثة فبدون اللغة و التو اصل بعيش الفرد ككائن حى، لكنه يو اجه صعوبة فـى البقاء كفرد اجتماعى اذ أنه يحرم من التفاعل مع من حوله، ويصبح أسبر عــالم

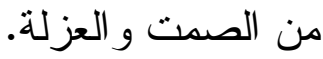

" معلم أول رياض أطفال بمدارس المنصورة الرسميت للغات. 
ومن هنا جاءت فكرة الدر اسة الحالية بمحاولة لعدـلـل برنـــامج تــدريبي لأطفال التوحد قائم على الوسائط المتعددة بنمى مهار ات التو اصل لــدى أطفــــال التوحد،إن فكرة التعلم عن طريق برنامج الوسائط المتعددة بــصوره وموســيقاه يمكن أن يحد من العزلة و الانسحاب لاى الطفل التوحدى.

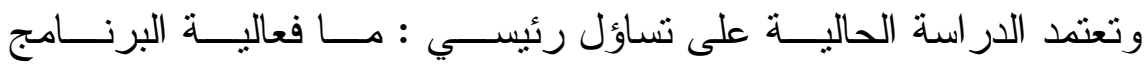

التدريبي القائم على الوسائط المتعددة لتحسين مهار ات التو اصــل لــدى اطفــال

$$
\text { التوحد؟ }
$$

وينبثق عن هذا السؤال الرئيسى التساؤلات الفرعية الأتية

ا ـ هل توجد فروق دالة بين متوسطات رتب درجــات اطفــال المجموعـــة

التجريبية قبل وبعد تطبيق برنامج الدر اسة الحالية على ( أبعاد و الدرجــة

$$
\text { الكلية) لمقياس مهار ات التو اصل؟ }
$$

r. هل توجد فروق دالة بين متوسطات رتب درجــات اطفــال المجموعـــة

التجريبية بعد التطبيق البرنامج ودرجاتهم بعد شهر من التطبيــق علـى

$$
\text { (أبعاد و الدرجة الكلية) لمقياس مهار ات التو اصل؟ لجدئ }
$$

\section{أهداف الدر اسة}

ا. معرفة مدى فعالية البرنامج التدريبي القائم على الوسائط المتعـددة فـى

$$
\text { تحسين مهار ات التو اصل لدى اطفال التوحد. }
$$

r. تقليل نمط اللعب التكرارى لأطفال التوحد وتقديم بدائل أخرى من خــله

$$
\text { برنامج الكمبيونز المستخدم فى الدر اسة. }
$$


1- زيادة الاهتمام بأطفال التوحد وتقيم مختلف أنو اع الرعايــة و الخــدمات النفسية و الإجتماعية التي تساعدهم على أن يحيو ا حياة سعيدة.

r- يمنل التعليم عن طريق بر امج الوسائط المتعددة وسيلة تعليمية وتنريييــة

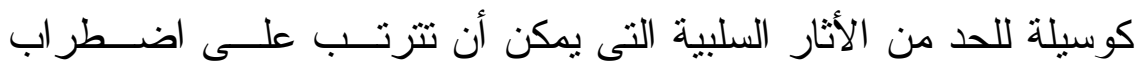

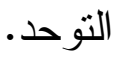

\section{المفاهيم الإجرائية للار اسة}

التوحد

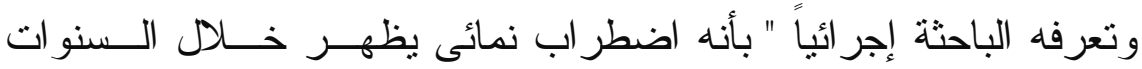

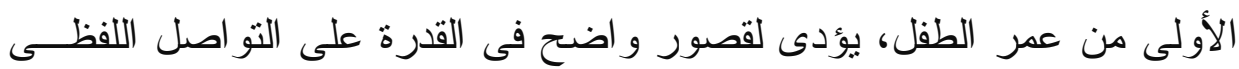

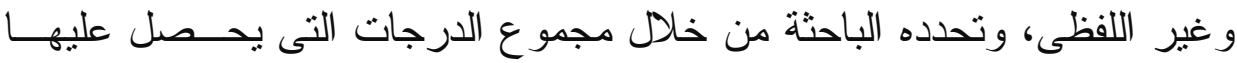
الطفل التوحدى بعد نطبيق مقياس جيليام المستخدم فى الدر اسة"

$$
\text { مهار }
$$

تعرفها الباحثة إجر ائيا بأنها : " مهارة استخدام الطفل اللغة الفظية وغيــر

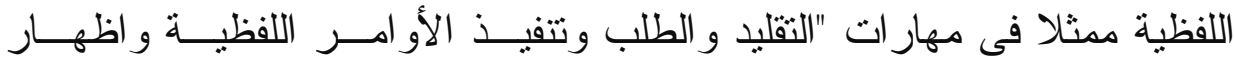

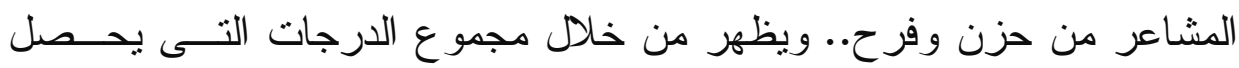
عليها الطفل بعد تطبيق مقياس مهار ات التو اصل المستخدم فى الدر اسة ".

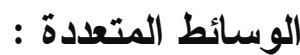

وهى أى موقف تعليمى استخدمت فيها الباحثة عدد من الوسائط، بما فـى

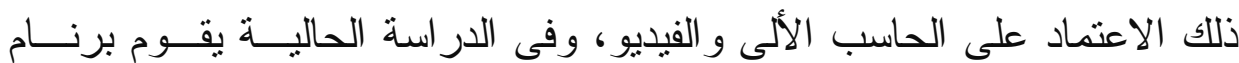


Power الوسائط المتعددة على استخدام برنامج عرض الثر ائح " مقدم العروض

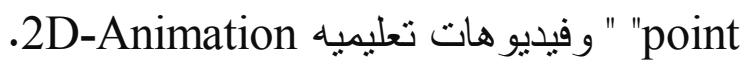
حدود الار اسة:

الحد الزمانى : استغرقت مدة تطبيق البرنامج إثنا عشرة أسبوع منتالية

$$
\text { فى (يناير } 9 \text { ( • ب/ابريل } 9 \text { 1 • ب ). }
$$

الحد المكانى : تم تطبيق الدر اسة الحالية بمركز" طيبة " تحــت اثتــر اف

وزارة التضامن الإجتماعي بحافظة الدقهلية.

الحد البشرى: تتمتل عينة الدراسة(ع) أطفال من ذوى اضطر اب التوحـــ

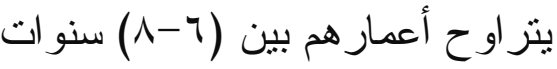

$$
\begin{aligned}
& \text { أولا : اضطر اب التوحد }
\end{aligned}
$$

ويعتبر اضطر اب التوحد خلا فى النمو العام للطفـلـ، و يظهـر خــلد

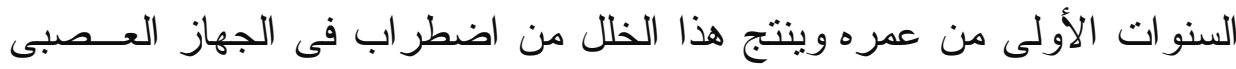

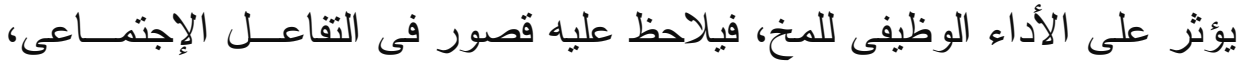

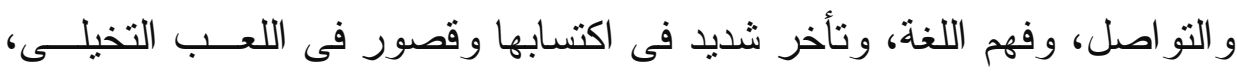

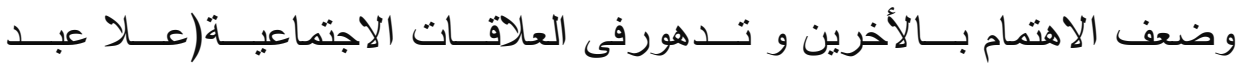

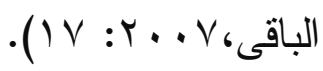

وتعرفه الجمعية القومية الأمريكية للأطفال التوحسديين ( NSAC ) أنـــه

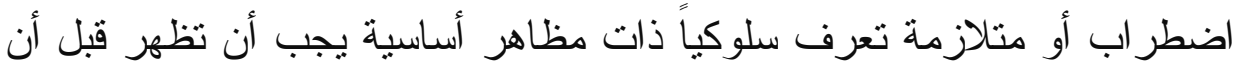

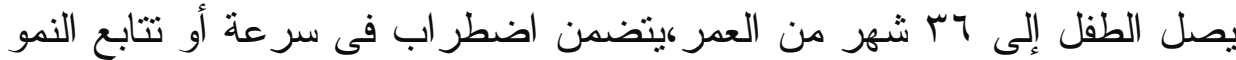


و الاستجابات الحسية للمثير ات و اضطر اب فى الكلام و اللغة و السعة المعرفيــة و الانتماء للناس و الأحداث و الموضو عات( محمود بدر، ؛ . . ب: 11 ) ثانيا : مهار ات التواصل

ويشير مفهوم "التو اصل" لعملية التفاعل بين الأفر اد و التى تهدف لتبــادل المعلومات و الأفكار و التعبير عن الحاجات و الرغبات، و التو اصل لا يحدث بدون مرسل للمعلومات ومستقبل لها، وقد يكون التو اصل لفظـى أو غبرلفظـى مــن خلال الإيماءات، الإثارة، نغمة الصوت، وتعبيرات الوجه، اللغة المكتوبة أو أى الى

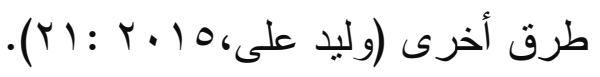

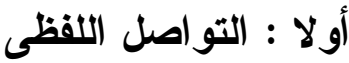
ويقصد به ذلك التو اصل الذى يعتمد على اللفظ كوسيلة لنقل رســالة مـن

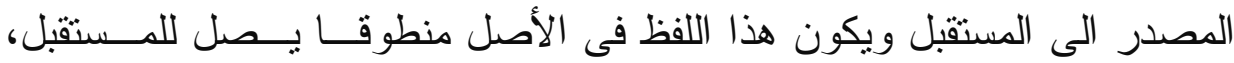

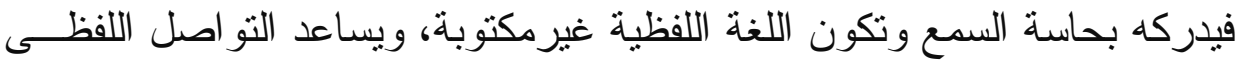
على النمو الاجتماعى و العقلى و المعرفى،عن طريق تزويده بالمهارات السلوكية

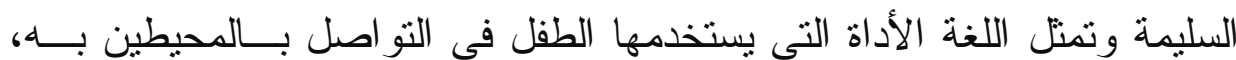

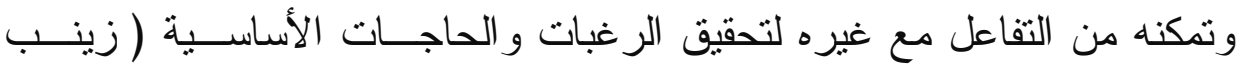

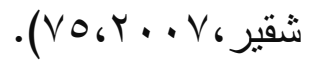
ثانيا : التو اصل غير اللفظى يقصد به تلاك الرسائل التى تصل إلينا عن طريق غيــر اللفظ،كتعبيــرات

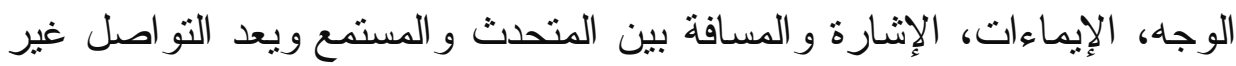
اللفظي من قنو ات التو اصل و التي تتضمن استخدام ملامح الوجـــة و الأوضــــاع

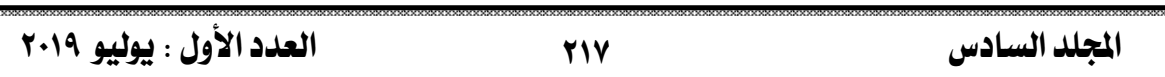


الجسيمة و الإيماءات، وتؤثر هذه الإثنار ات في تيسير التو اصــل و التفاعـل مـــع الآخرين (Anne et al.,2014:31).

ومن هنا يمكن تعريف مهار ات التواصل اجر ائيا : بأنـــهـ القـدرة علـى استخدام وظائف اللغة بصورة لفظية أؤ غيرلفظية للتو اصل مع الأخرين بفعالية وتتضمن وظائف اللغة مجموعة مــن الدهــار ات " التو اصـلـل البــصرى، التقليد

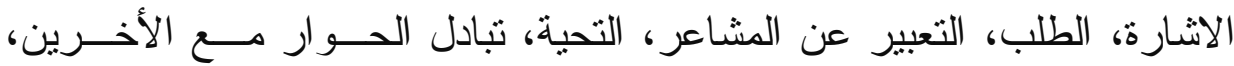

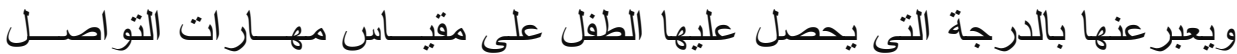
المستخدم فى الدر اسة

ثالثا : البرنامج الاكترونى القائم على الوسائط المتعددة

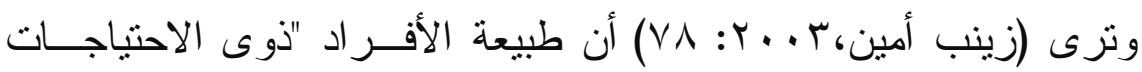

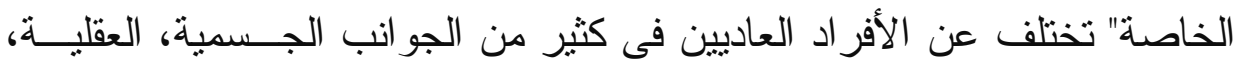
النفسية، و الحركية وهذا بالضرورة يحتم وجود بر امج تربوية خاصسـة بهـؤلاء لهاء

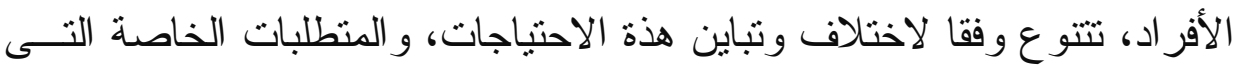
ينبغى مساندتها.

\section{برامج الكمبيوتر متعددة الوسائط}

بر امج الكمبيوتز متعددة الوسائط " تعنى استخدام مجموعة مسـن وســائل

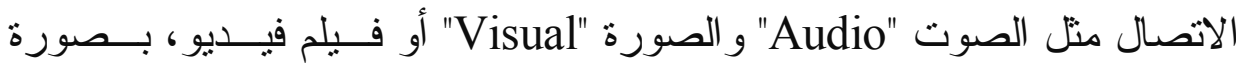

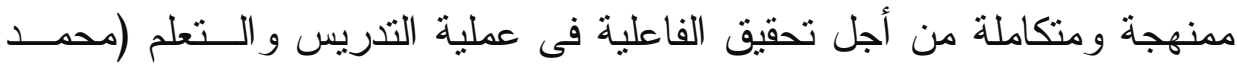

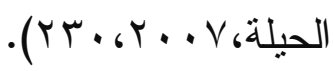


ومن هنا تعرف الباحثةة برنامج الوسائط المتعـددة "'وهــى أى موقــف

تعليمى استخدمت فيه الباحثة عدد من الوسائط المتعددة، بما فى ذلـــــ الاعتمــاد على الكمبيوتز و الفيديو، وفى الدر اسة الحالية يقوم برنامج الوسائط المتعددة على استخدام عرض الثر ائح " مقدم العروض Powerpoint" وفيــديو هات تعليميــــ قائمة على 2D Animation استخدام الكمبيوتر مع التوحديين ويوجد العديد من التطبيقات الحديثة للهاتف الجوال و أجهــزة الكمبيــوتز و التى صممت خصيصـا لمساعدة الأطفال التوحديين فعلى سبيل المثــال بــر امج لتحسين مهار ات التو اصل الاجتماعى look at me " وبـــر امج أخــرى تـساند متطلبات النمو فى مهار ار ات الحياة اليومية ومن أهمها "LLA "، و أخر يت مهدر قائمة اللغة و الكلام "المحادثات"( Barbra et al. ., 2013: 65 ) ويستخدم الكمبيوتز فى تتمية العديد من المهار ات لدى الأطفال التوحـديين منل التو اصل اللغوى و التفاعل الاجتماعى من خلال أنشطة منل: اللعب و الرســـ و الاعتماد على الذات (Teresacordon , 2016:94). عناصر التعليم بمساعدة الكمبيوتز النص Text : ان النص من العناصر الفعالة فى تطبيق بر امج الكمبيوتز

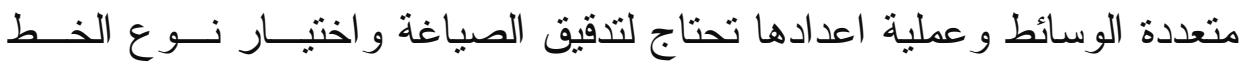
و اللون المناسب وطريقة العرض. والصوت Sound: يمنل الصوت دور ا مهما خاصة و أنه يـستخدم فـى أغلب الأوقات كبديل أفضل من النص (طارق عامر ، 10 • ؟ 9 9) 


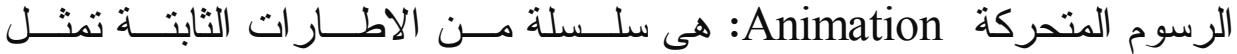

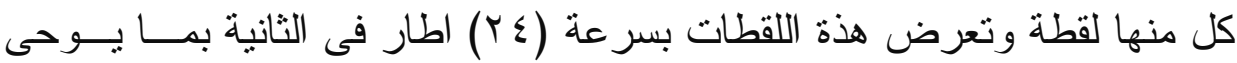
للمشاهد بالحركة و الصور الثابتة Still picture: هى لقطــات ســاكنة لأثــياء حقيقية أو تخيلية يمكن عرضها لأى فترة زمنية وتؤخذ من الكتب و المجلات عن

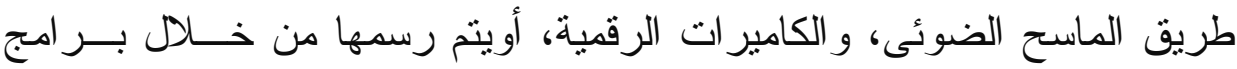
معينة ويمكن اضافة المؤثرات لها عن طريق الكمبيوتر( كمال زيتون، ب... ب :

أسس بناء برامج الكمبيوتر إن أى برنامج يقدم لهذة الفئة يجب أن ير اعى لَ ا ـ تحديد أهداف صريحة وو اضحة. r. التعرف على مر اكز القوى لدى الطالب. r. تميز ها بالمرونة و القابلية للتعديل و التغيير. ع. اتساقها مع الأهداف التعليمية.

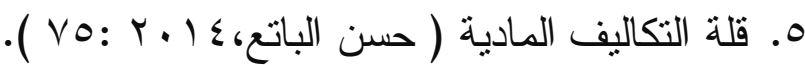
أولاً: دراسات اهتمت بمهارات التواصل لدى الطقل التوحىى بينما هدفت در اسة (دلثا على، • 1 • ) ) إلى معرفة فاعلية برنامج تدريبى

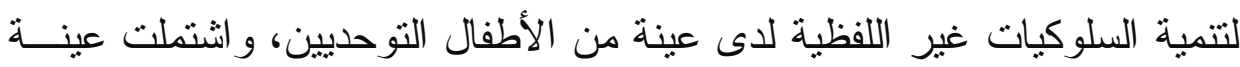
الدر اسة ^ أطفال توحديين أعمار هم بين (ع-^) سنوات وقام الباحث ببناء قائمة

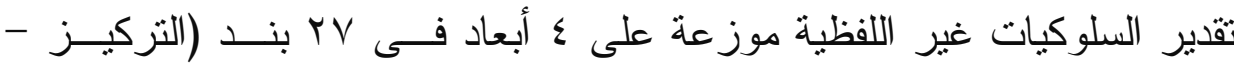
الانتباة و التقليد - التواصل الاثشارى- الايماءات و الأوضاع الجسدية -التعبيرات 
الانفعالية ) وتم استخدام مقياس كارز للتعرف على درجة التوحد لــدى أطفــال العينة، وتوصلت نتائج الدراسة : الى فاعلية البرنامج التدريبى المســخدم فـى تتمية السلوكيات غير اللفظية على عينة البحث ولكن بــدرجات متفاوتــة، كسـان أكبر ها فى النركيز و الانتباة و أقلها فى الإيماءات و الأوضاع عليه الجسدية.

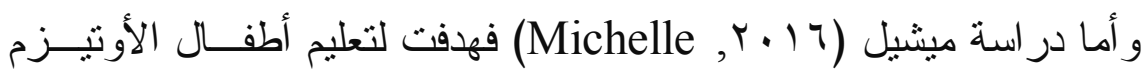

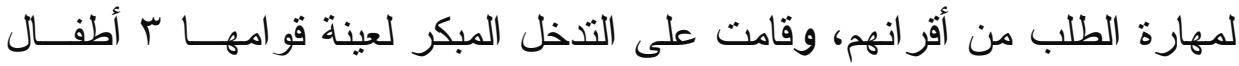

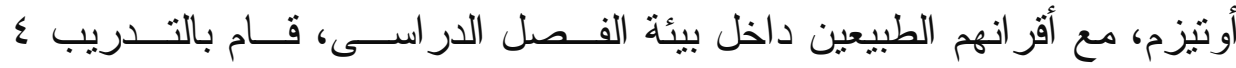

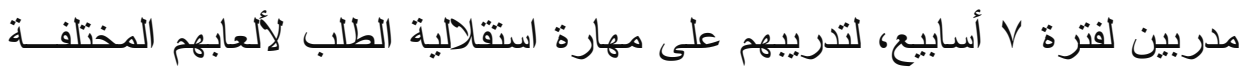
من أقر انهم الطبيعين، و جاءت النتائج تؤكد على ضرورة التخخل بتعليم مهــارة

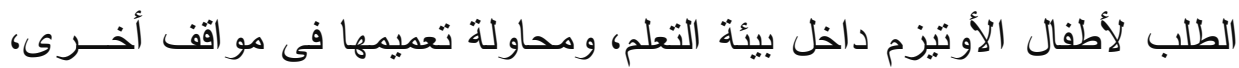
بالاضافة الى استفادة أطفال الأوتيزم من الجهود المبذولة لزيادة الوظائف اللغوية

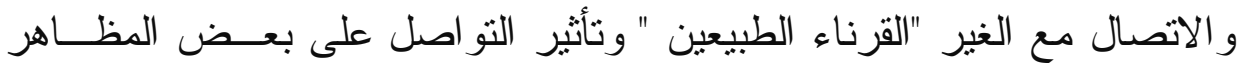

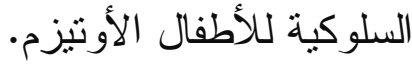

\section{ثانياً: دراسات اهتمت باستخدام الوسائط المتعدده مع أطفال التوحد} و هدفت دراسة اليكسس Alexis (2004 ,) لمعرفة تأثير ألعاب الكمبيوتر

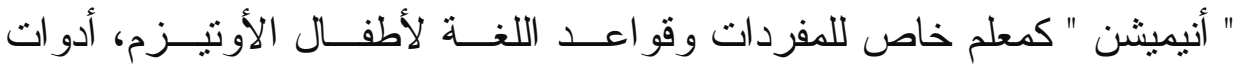
الدر اسة : لعبة "أنيميثن تسمى (Baldi ) تم تـصميمة كمعلـم خــاص لتعلــيم

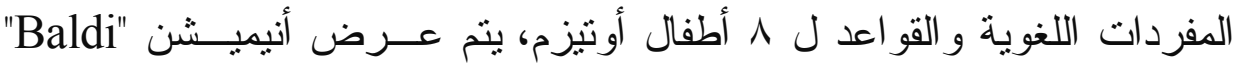
على جهاز الكمبيوتز و الذى من خلاله يتم عرض و اظهار دروس اللغة متضمنة الصور و الكلمات المنطوقة، تم تعريف الأطفال بالأنيميشن و اتباع التعليمات مسنـ خلاله، بعد مرور • بـ يوم من التدريب على المساعدة عن طريق "Baldi"، تـــ 
اختبار الأطفال فى مجمو عة الدفردات الجديدة التى تم تعلمها، نتــائج الدر اســـة:

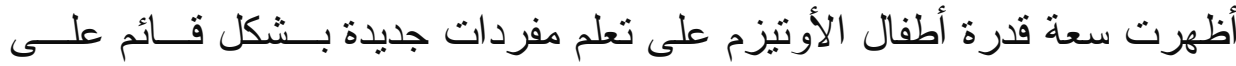
ألعاب الكمبيوتز ، وكانت مشاركتهم فعالة في استخدام اللغة فى بيئته وتعميمهــا

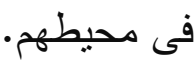

و هدفت در اسة (فهد العمر ، • • ب) الى فاعلية برنامج محوسب فى تطوير

مهار ات التو اصل لاى الأطفال التوحديين فى منطقة الرياض، أدوات الدر اســـة :

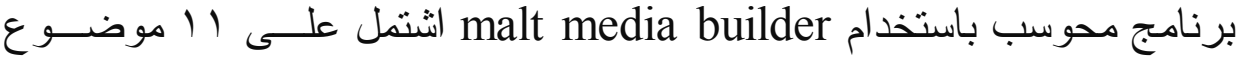

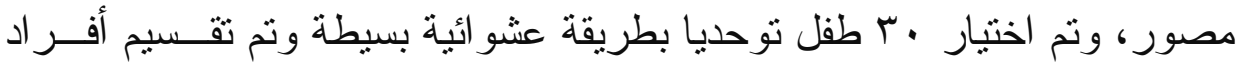
العينة بشكل عشو ائى لمجمو عتين، تجرييية 10 طفل، ضابطة مسن 10 طفــل، و استخدم الباحث مقياس فانيلاند للسلوك التكيفى، واستمر تطبيق البرنامج شـــر

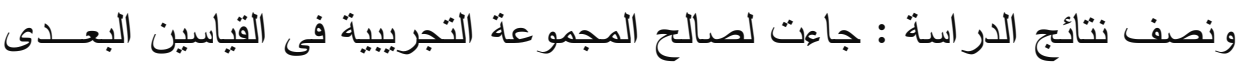
و التتبعى

ودر اسة ماجى (2013،Maggie ) هدفت لرفع مستوى الوظيفة اللغويــة

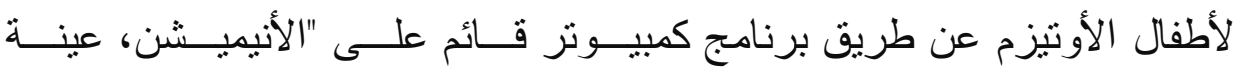

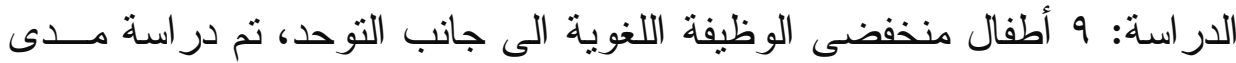

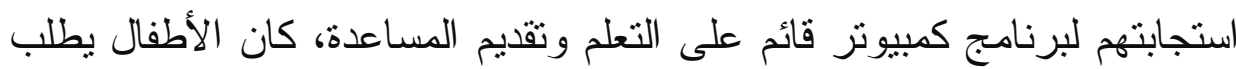
منهم لمس الكلمات على شانثة الكمبيوتر فى شكل مجموعة من المهار ات اللغوية

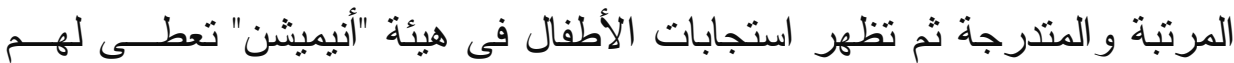

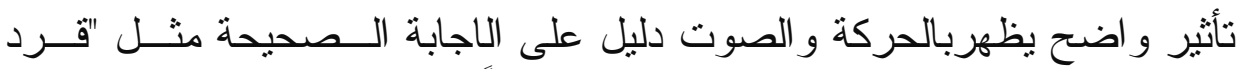

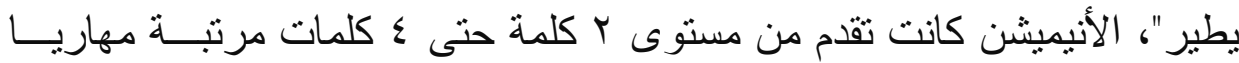
وفى نهاية كل مرحلة لابد وأن يصل الطفل لمستوى معين من الدحاو لات حتى كلى

المجلد السادس


اجر اعات الار اسة

أولاً : منهج الدراسة

استخدمت الباحثة فى الدراسة الحالية المنهج شبه التجريبي لتطبيق برنامج

تدريبى قائم على الوسائط المتعددة لتحسين مهار ات التو اصل لدى اطفال التوحد،

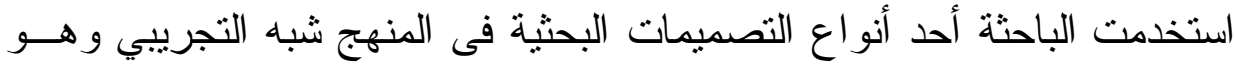
التصميم القبلى - البعدى - التتبعى للمجمو عة التجرييية الو احدة.

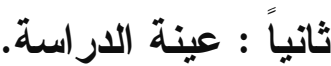

\section{وصف العينة}

ضمت عينة البحث ( ع ) أطفال من التوحد، معامل ذكاؤهم يتــر اوح بــين

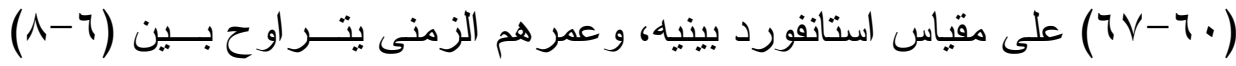

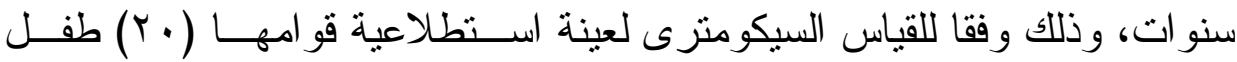

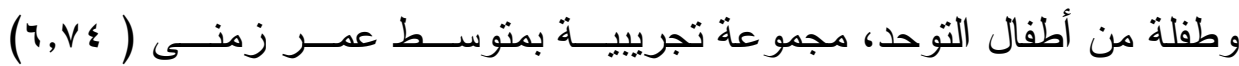
وبإنحر اف معيارى مقداره ( ^.^, • •)

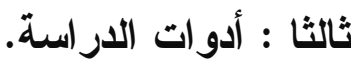

1. اختبار الذكاء ستانفورد بينيه (ترجمة و تقنين صفوت فرج، ؟ . ب؟) r. مقياس جيليام لتقدير درجة الذاتوية ( تعريب و تقنين / عادل عبــــ الله،

$(r \cdots v$

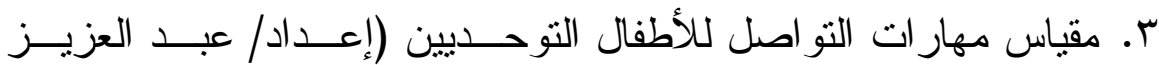

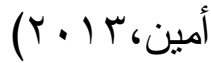
ع. برنامج الوسائط المتعددة (اعداد / الباحثة ) 


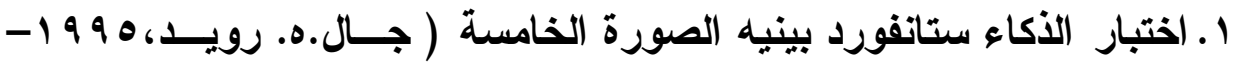

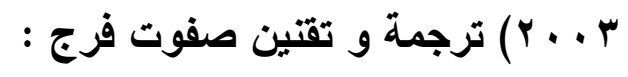

يهذف هذا المقياس الى قياس نسبة الذكاء و القدر ات المعرفية، وهو ملائسـم للمفحوصين من عمر عامين وحتى الخامسة و الثمانين فأكثر ، ويتضمن المقيــاس الفاس

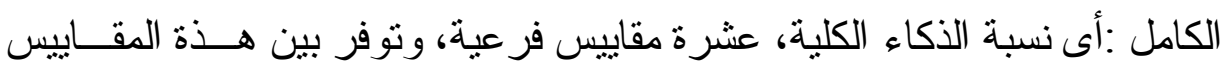

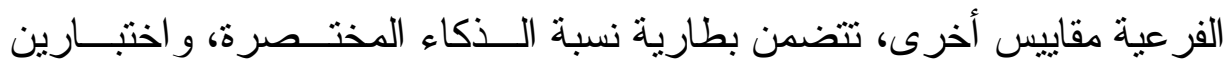
مدخليين فر عيين هما سلاسل الأثنياءو المصفوفات، و المفر ادات، ويمكن استخدامه

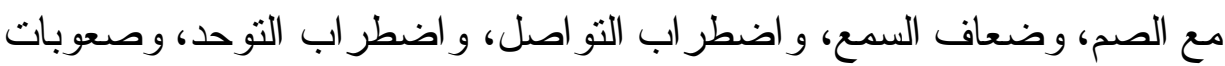
التعلم، و اعاقات الثلل المخى، و الاصيابات المخية الصدمية، r. مقياس جيليام لتقدير درجة الذاتوية ( تعريب و تقتـين / عسـادل عبـــ الله

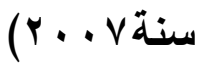

صمم المقياس وقام باعداده جيمس جيليام كأداة عالية الثبــات مــن أجـل تشخيص الأشخاص التوحديين،و الذى يمثل الهدف الأساسى للمقياس، ويتكون من

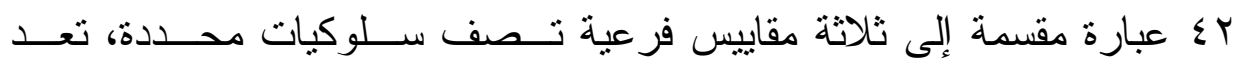

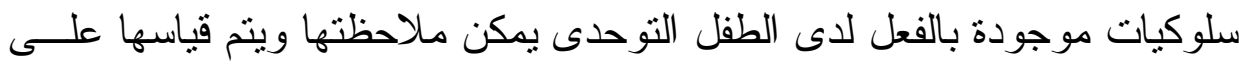

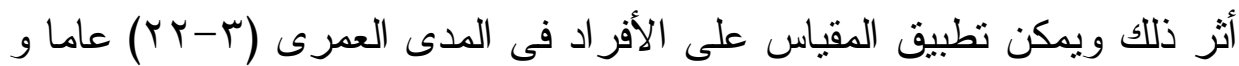
يعد كل مقياس فرعى من المقاييس الأربعة هو اختبار مستقلا فى ذاتها، يمكن أن الن يتم تطبيقه بمفرده أو دون سو اه في في البحوث المختلفة. r.مقياس مهارات التواصـل للأطفــال التوحـديين (إعـــداد/ عبــــ العزيـز

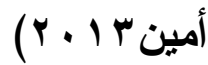
الهيف من اعداد المقياس قام معد المقياس باعــداد هـــة الأداة بغــرض

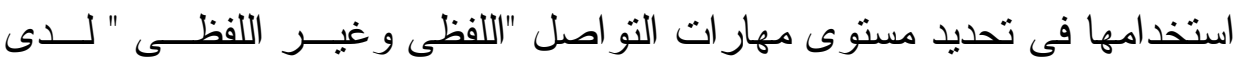

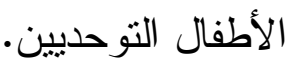


وصف المقياس :تكون المقياس فى شكله النهائى من (Y0) عبارة تقـيس مهار ات التو اصل "اللفظى و غير اللفظى " لدى الأطفال التوحديين صدق المقياس : تم حساب صدق المقياس كما يلى قام معد المقياس بإيجاد التجانس الداخلى للمقياس عن طريـق حـسـاب معامل الارتباط بين درجات الأفر اد على كل عبارة من عبار ات المقياس، و البعد الذى تتنمى إليه وجاءت جميع قيم معاملات الارتباط دالة احصائيا عند مسستوى

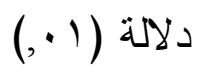

قيم معاملات الارتباط بين درجات الأفراد على كل عبارة من عبار ات مقياس مهار ات التواصل والبعد الأى تتنمى إليه

\begin{tabular}{|c|c|c|c|c|c|c|c|}
\hline \multicolumn{7}{|c|}{ العبارات } & الأبعاد \\
\hline 17 & ir & 1. & v & $\varepsilon$ & 1 & رقم العبارة & \multirow{4}{*}{ اللفو اصل } \\
\hline$\cdot, \leqslant 91$ & ., $\leqslant 11$ & . rAv & ., $\leqslant 97$ & r OrY & . , $\leqslant V r$ & معامل الإرتباط & \\
\hline ع & r & rA & ro & rr & 19 & رقم العبارة & \\
\hline$\cdot,\{, 0$ & . &., $0 \leqslant 9$ & $\cdot, \leqslant \wedge 1$ & דrt, & .,Or. & معامل الإرتباط & \\
\hline IV & $1 \leqslant$ & 11 & $\wedge$ & 0 & r & رقم العبارة & \multirow{4}{*}{ اللتول التير } \\
\hline וor, & צ० & . r, $\Delta q$ & $\cdot, \leqslant Y V$ & • & .,OY & معامل الإرتباط & \\
\hline ק & rr & rq & צ & r & r. & رقم العبارة & \\
\hline., 2517 &., 000 & . , \&०V & $\cdot, \varepsilon \leqslant r$ & ., 0.0 & O & معامل الإرتباط & \\
\hline
\end{tabular}

ثم قام معد المقياس بايجاد معامل الارنباط بين درجات الأطفــال علــى الدرجة الكلية للبعد و الدرجة الكلية للمقياس. 
معامل الارتباط على الدرجة الكلية للبعد والدرجة الكلية للمقياس

\begin{tabular}{|c|c|}
\hline معامل الارتباط & الأبعاد \\
\hline צזד & التواصل اللفظى \\
\hline, $0 \leqslant 9$ & لتواصل غير اللفظى \\
\hline
\end{tabular}

يتضح أن جميع قيم معاملات الارتباط دالة احصائيا عند مستوى دلالـــة

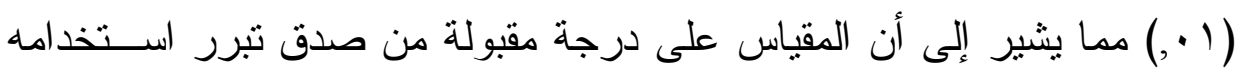

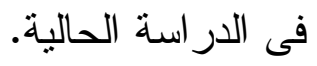
ثبات المقياس

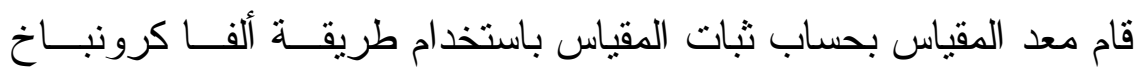
وطريقة اعادة تطبيق المقياس بفاصل زمنى قدرة اسبوعين بين النطبيـق الأول و الثانى

قيم معاملات ثبات أبعاد المقياس والدرجة الكلية بطريقتي إعادة التطبيق ومعامل ألفا كرونباخ

\begin{tabular}{|c|c|c|}
\hline طريقة اعادة التطبيق & طريقة ألفا كرونباخ & 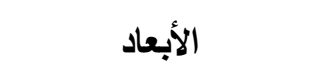 \\
\hline , 119 & , A11 & التواصل اللفظى \\
\hline,$A .7$ & , var & التو اصل غير اللفظى \\
\hline , $\wedge r v$ & , Arq & الدرجة الكلية للمقياس \\
\hline
\end{tabular}

تنتير النتائج إلى أن المقياس على درجة مقبولة من الثبات تبرر استخدامه

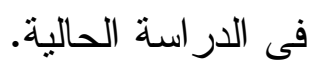


ثم قام معد المقياس بوضع مفتاح لتصديح المقياس وفيــهـ يطلــبـــــن القــائم

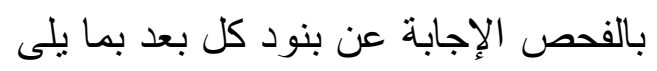

$$
\text { دائما =r درجات، أحيانا=r درجة، نادر | = ا درجة }
$$

ثم قامت الباحثة فى الدراسة الحالية بحساب ثبات وصدق الاختبار لمقياس مهار ات التو اصل على عينة قو امها (·r) طفل توحدى عن طريق حساب معامل الارتباط بين الدرجة الدفردة ودرجة البعد الذى تتنمى إليه قيم معاملات الارتباط بين درجات الأفر اد على كل عبارة من

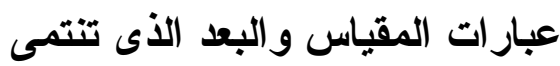

\begin{tabular}{|c|c|c|c|c|c|c|c|}
\hline \multicolumn{7}{|c|}{ العبار ات } & الأبعاد \\
\hline 17 & ir & 1. & $v$ & $\varepsilon$ & 1 & رقم العبارة & \multirow{4}{*}{ اللفو اصل } \\
\hline$* *, 0,7$ & 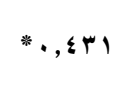 & $*,, \leqslant r q$ & $* *, \vee \vee \vee \leq$ & $*$ •, $\leqslant 77$ & "**・, • & معامل الإرتباط & \\
\hline$r \varepsilon$ & rl & rᄉ & ro & rr & 19 & رقم العبارة & \\
\hline ***, • ฯ & $*,, \leq \leqslant r$ & $* *,, \leq V 1$ & $* *, \neg \vee \wedge$ & $* *$, * $\leqslant$. & $* *, \vee \backslash \wedge$ & معامل الإرتباط & \\
\hline iv & $1 \varepsilon$ & 11 & $\wedge$ & • & r & رقم العبارة & \multirow{4}{*}{ التواصل } \\
\hline$* *, O Y 1$ & $* *, \wedge, \diamond$ & $* *, 794$ & $* *, \vee \backslash V$ & $* \ldots$ & $* *$, * & معامل الإرتباط & \\
\hline ro & rr & rq & rq & $r r$ & $r$. & رقم العبارة & \\
\hline$* *, 001$ & $* *, 017$ & $* *, \nearrow \mid r$ & $* *, V Y l$ & 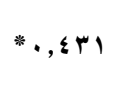 & **, • ๑ \& & الإرتباط معامل & \\
\hline
\end{tabular}

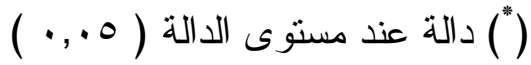
(") (") دالة عند مستوى الدالة (1 ., • ) 
ويتضح من النتائج أن قيم معامل ارتباط درجة كل مفردة بالدرجة الكليــة

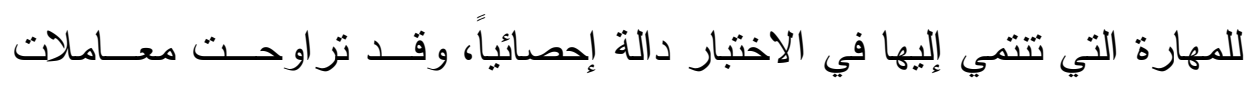

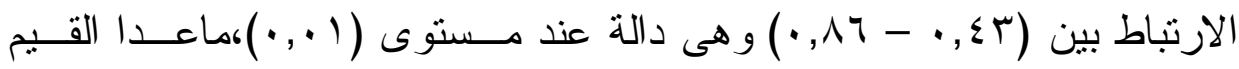

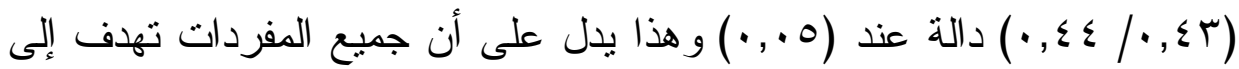
قياس الأبعاد التي تتنمي إليها في الاختبار . داه معامل الارتباط بين الارجة الكلية للبعد و الارجة الكلية للمقياس

\begin{tabular}{|c|c|}
\hline معامل الارتباط & الأبعاد \\
\hline $.763 * *$ & التواصل اللفظى \\
\hline $.721^{* *}$ & التواصل غير اللفظى \\
\hline $.851^{* *}$ & الدرجة الكلية \\
\hline
\end{tabular}

يتضح أن جميع قيم معاملات الارتباط دالة احصائيا عند مسـستوى دلالـــة

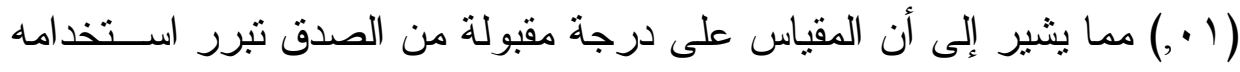
فى الدر اسة الحالية. ع) معامل الارنباط بين الدحورين ( التواصل اللفظي - التو اصــل غيــر الفظي ) و مقياس مهار ات التواصل للطفل الذانوى يتر اوح بين (0.851 - 0.721)

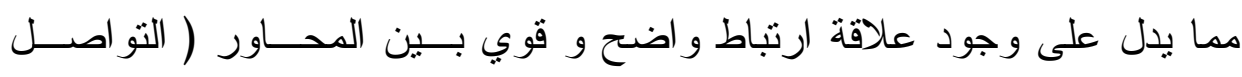

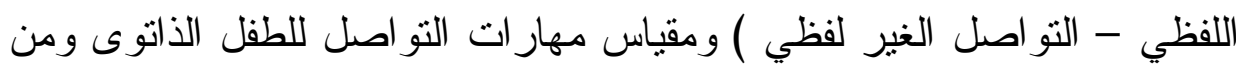
ثم يمكننا القول أن هناك صدق في المقياس ككل. 
قامت الباحثة بحساب ثبات المقياس باستخدام معامل ألفاكرونباخ حيــث

تز اوح قيم معاملات الإرتباط بين الأبعاد المقيــاس و الدرجــة الكليــة (9 ه, . -

قيم معاملات ثبات أبعاد المقياس والارجة الكلية بطريقة معامل ألفا كرونباخ

\begin{tabular}{|c|c|c|}
\hline طريقة الفاكرونباخ & عدد المفردات & الطريقة \\
\hline$\cdot 0.761$ & 12 & التواصل اللفظي \\
\hline 0.597 & 12 & التواصل الغير لفظي \\
\hline 0.867 & 24 & الاختبار ككل \\
\hline
\end{tabular}

تشير النتائج إلى أن المقياس على درجة مقبولة من التبات نبرر استخدامه

$$
\text { فى الدر اسة }
$$

البرنامج التعليمي القائم على الوسائط المتعددة (اعداد الباحثة) وتعرفة الباحثة اجر ائيا بأنه" مجمو عة من الوسائط المتعددة يــتم وضـــها بشكل منز ابط ومتكامل مكونة برنامج تدريبى الكترونى بساعد الطفل التوحــدى على تتمية مهار ات التو اصل وتتحقق بالدرجة التى يحصل عليها الطفـلـل علـىى مقياس مهار ات التو اصل مكلى

أهمية البرنامـج وترجع أهمية البرنامج أنه يقوم علــى تتميــة مهــار ات

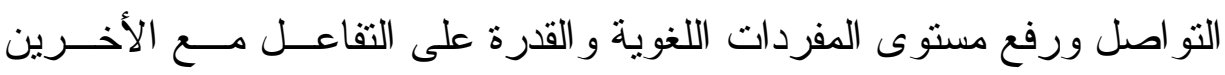
و التى تجعلهم أكثر تقبلا فى المجتمع. 
مصادر بناء البرنامـج و اعتمدت الباحثة فى اعداد البرنــامج علــى عـدة

$$
\text { مصادرمنها }
$$

قر اعة الاطار النظرى للار اسة و الذى تم عرضة تفــصيليا فـى الفــصل

الثانى،الدر اسات العربية و الأجنبية السابقة و التى تمكنت الباحثة مــن الحـصول عليها وتم عرضها تفصيليا فى الفصل الثالث من الدر اسة. المر احل التى مر بها البرنامجج المرحلة الأولى : "تهيئة" وتهدف إلى خلق روح من الألفة و المــودة بــين الباحثة و الأطفال عينة الدر اسة، و التعرف على أهم معزز ات الطفل و اسـتـغرقت هذة المرحلة جلستان مدة الجلسة . ب دقيقة. المرحلة الثانية : وهى المرحلة التى تم فيها تطبيق البرنامج و التى مثلت التدريب على الأهداف الاجر ائية التى اتخذها البرنامج من خلال الجلسات بو اقع بץ جلسة،مدة الجلسة ( • ب) دقيقة. المرحلة الثالثة : المرحلة التى تم فيها عمل اختبار ات نهائية للتأكد مـنـ

$$
\text { مدى تحقق أهداف البرنامج }
$$

أساليب التقييم المستخدمة للبرنامج

التقييم القبلى وهو القياس الذى يتم قبل تطبيق البرنامج، بتطبيق مقيــاس مهار ات التو اصل على العينة المشاركة فى البرنامج. التقييم البعدى و هو القياس البعدى حيث يتم تقييم أثز البرنامج الالكترونى القائم على الوسائط المتعددة فى الدر اسة الحالية لتتمية مهار ات التو اصل للطفــلـ

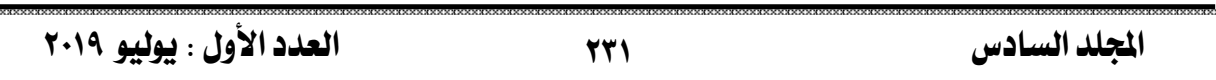


التوحدى، من خلال اعادة تطبيق مقياس مهار ات التو اصــل ومقارنـــة النتــائج ببعضها البعض.

التقييم التتبعى وهو القياس التتبعى وتم تطبيقه بعد مـرور شــر مـن

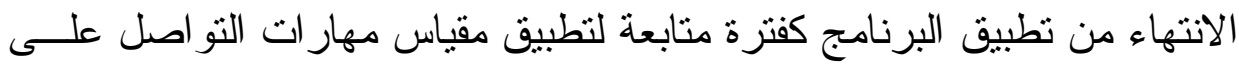
الأطفال التوحديين، ومعرفة مدى استمر ارية تحقيق الهدف العام من البرنامج. خامساً: : جراعات الدر اسة والأساليب الإحصائية المستخدمة

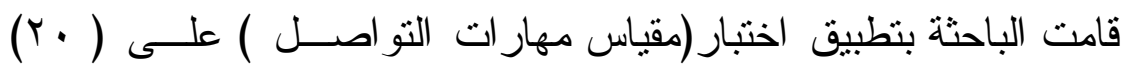

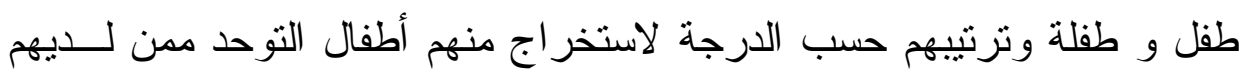

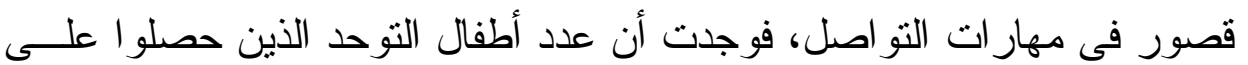
درجات منخفضة على مقياس مهار ات التو اصل( ع) أطفال.

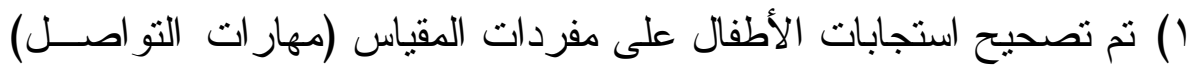

$$
\text { وحصر درجاتهم. }
$$

r) ثم قامت الباحثة بالتحقق من التكافؤ بين أفراد المجموعة من حيث: العمر

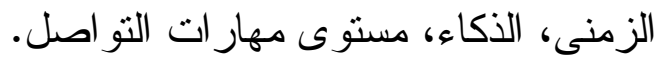

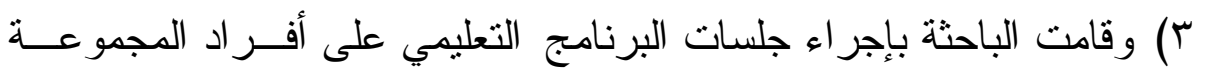

$$
\text { التجرييية. }
$$

ع) تم تطبيق مقياس مهار ات التواصل - كمقيــاس بعـدى - علــى أفــر اد المجموعة التجريبية - بعد الانتهاء من جلسات البرنامج التعليمى القـائم

$$
\text { على الوسائط المتعددة. }
$$

0) بعد الاتتهاء من تطبيق البرنامج التعليمى القائم على الوســائط المتعـددة

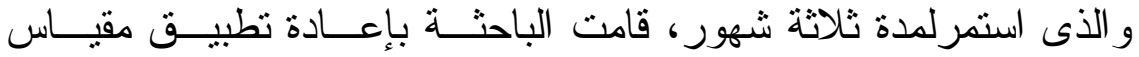

المجلد السادس


مهار ات التو اصل على أفر اد المجموعة التجريبية لمعرفة ددى اســتمرار فاعليته بعد شهر من التطبيق.

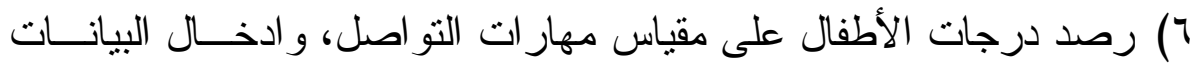

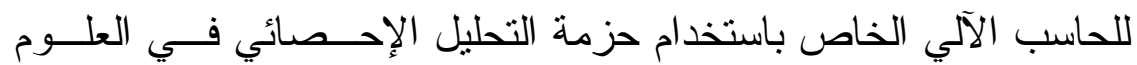
الإنسانية SPSS ( استخدمت الباحثة الأساليب الإحصائية الآتية

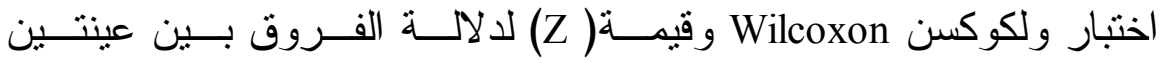
مرتبطتين. ايجاد معاملات الثبات بطريقة الفاكرونباخ،و طريقة اعادة الاختبار .

نتائج الدر اسة ومناقثتها و تفسير ها. نتائج الفرض الأول

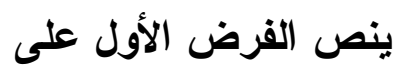

" توجد فروق ذات دلاله إحصائيه بين متوسطات رتب درجــات أطفــال

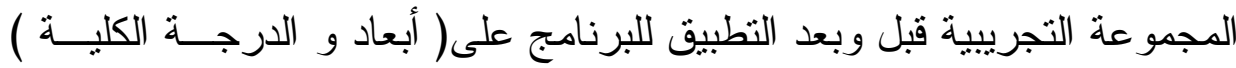
لكقياس مهار ات التو اصل لصالح القياس البعدى ".

وللتحقــق مـن صــحة الفـرض اســتخدمت الباحثــة اختبــار "

ولكوكسن" Wilcoxon لدلالة الفروق بين متوسطات رتـب درجــات العينــات

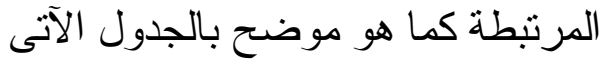


الفروق بين متوسطات رتب درجات أفر اد المجموعة التجريبيــة، قبــل تطبيق البرنامـج وبعد التطبيق على مقيــاس مهــارات التواصــل بإســتخدم

ولكوكسن Wilcoxon

\begin{tabular}{|c|c|c|c|c|c|c|}
\hline مستوي & $\mathbf{Z}$ & مجموع الرتب & متوسط & العدد & القبلى_البعدى القياس & البعد \\
\hline 0.01 & 6.310 & $\begin{array}{c}.00 \\
10.00\end{array}$ & $\begin{array}{l}.00 \\
2.50\end{array}$ & $\begin{array}{l}0 \\
4 \\
0 \\
4\end{array}$ & الر الرتب المبت المالبة & تو اصل لفظي \\
\hline 0.01 & 5.621 & $\begin{array}{c}.00 \\
10.00\end{array}$ & $\begin{array}{l}.00 \\
2.50\end{array}$ & $\begin{array}{l}0 \\
4 \\
0 \\
4\end{array}$ & الر الرتب الموجبة المالبة & تو اصل غير لفظي \\
\hline 0.01 & 7.480 & $\begin{array}{c}.00 \\
10.00\end{array}$ & $\begin{array}{l}.00 \\
2.50\end{array}$ & $\begin{array}{l}0 \\
4 \\
0 \\
4\end{array}$ & الر الرتب الموجبة المالبة & الدرجة الكلية \\
\hline
\end{tabular}

يتضح من الجدول السابق ما يأتى - بالنسبة لبعد التواصل اللفظي:

توجد فروق ذات دلالة إحصائية بين كل من ( التطبيق القبلى و البعـدى )

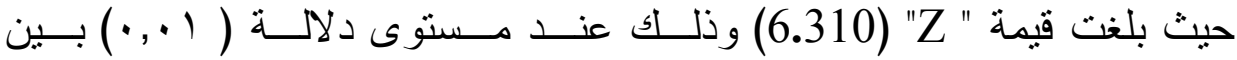
متوسطات رتب درجات أفر اد المجموعة التجريبية، قبل تطبيق البرنامج وبعـد التطبيق لصالح القياس البعدى 
- بالنسبة لبعد التواصل غير اللفظي

توجد فروق ذات دلالة إحصائية بين كل من ( التطبيق القبلى و البعـى )

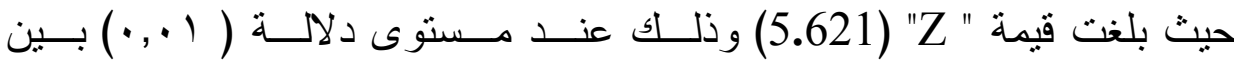

متوسطات رتب درجات أفر اد المجموعة التجريبية، قبل تطبيق البرنامج وبعـــ

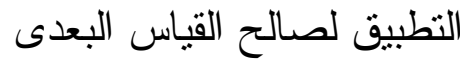

- بالنسبة للارجة الكلية للمقياس

توجد فروق ذات دلالة إحصائية بين كل من ( النطبيق القبلى و البعـى )

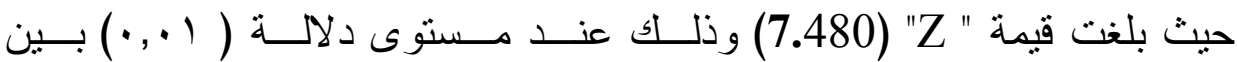
متوسطات رتب درجات أفر اد المجموعة التجريبية، قبل تطبيق البرنامج وبعـــ

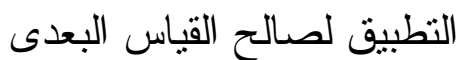

ويشير ذلك ارتفاع مهار ات التو اصل لدى أطفال المجموعة التجريبية بعد.

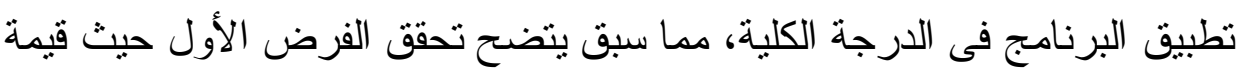
لد لالالة الفروق بين بين منوسطات رتب درجات أفر اد المجموعة التجرييــــة قبل وبعد التطبيق للبرنامج التعليمي القائم على الوسائط المتعـددة علــى أبعـاد مقياس مهار ات التو اصل لصالح القياس البعدى.

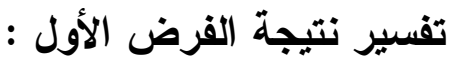

ويمكن مناقثنة نتيجة الفرض الأول فى ضوء المعايير التى تم الاعتمـاد عليها وكذلك الأدو ات و الفنيات المتضمنه فى البرنامج ويمكن إرجاع هذا التحسن و التطور فى المهار ات إلى فلسفة البرنامج و المعايير التى احتكمت لها الدراســة 
أثناء تطبيق الجلسات حيث تم مر اعاة اختيار أنثطة البرنامج بــــا يتتاســب مــع طبيعة فئة العينة من حيث درجة التوحد و العمر الزمنى ودرجة الذكاء.

و هذا ما أوضحته در اسة "كوثر قو اسمهـ ب بـ " حيث أكدت على أهميــة

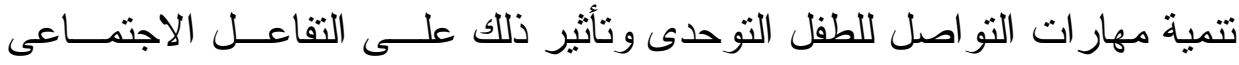
حيث يعبر الطفل عن طريق مهارة التو اصل غير اللفظى عن رغباته ومسـشاعرة

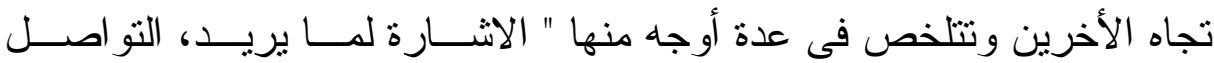

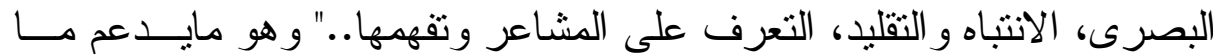

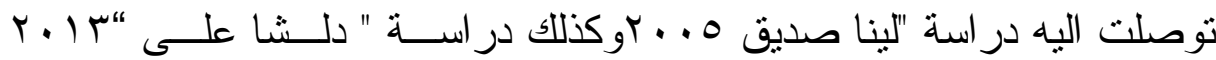
" carol2008 "Vincent carbon 2012

أى أن البر امج المقدمة لتلك الفئة تستطيع أن تتمى بعض المهارات التـى

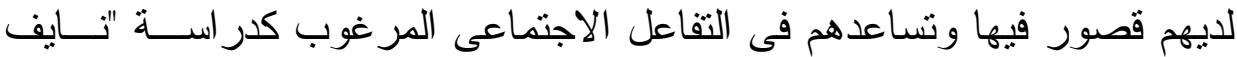

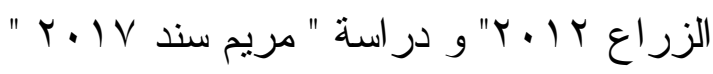
نتائج الفرض الثانى

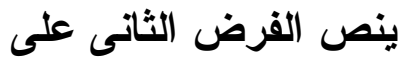

" لا توجد فروق ذات دلاله إحصائيه بين منوسطات رثب درجات أطفــال المجموعة التجريبية فى القياس البعدى ومتوسطات درجاتهم فى القياس التتبعى

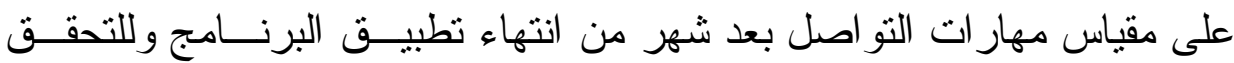
من صحة الفرض استخدمت الباحثة اختبار " ولكوكسـسن" Wilcoxon لدلالـــة الفروق بين متوسطات رنب درجات العينات المرتبطة كما هو موضح بالجدول التالى 
الفروق بين متوسطات رتب درجات أفراد المجموعة التجريبية، بعـــ تطبيـق البرنامج وبعد شهر من التطبيق على مقياس مهــارات التواصـلـل بإســتخدام

ولكوكسن Wilcoxon

\begin{tabular}{|c|c|c|c|c|c|c|}
\hline مستوي & $\mathbf{Z}$ & مجموع & متوسط & العدد & البعدى _التبتعى & البعد \\
\hline غير دالة & 1.604 & $\begin{array}{c}.00 \\
6.00\end{array}$ & $\begin{array}{c}.00 \\
2.00\end{array}$ & $\begin{array}{l}0 \\
3 \\
1 \\
4\end{array}$ & الرتب الرتب الموجبة المتالبة & توظي \\
\hline غير دالة & 1.000 & $\begin{array}{c}.00 \\
1.00\end{array}$ & $\begin{array}{c}.00 \\
1.00\end{array}$ & $\begin{array}{l}0 \\
1 \\
3 \\
4\end{array}$ & الرتب الرتب الموجبة المتبالية & تواصل غير \\
\hline غير دالة & 1.841 & $\begin{array}{l}10.00 \\
.000\end{array}$ & $\begin{array}{l}2.50 \\
.000\end{array}$ & $\begin{array}{l}0 \\
3 \\
1 \\
4\end{array}$ & الرالب الرتب الموجبة المتبالية & الالارجة \\
\hline
\end{tabular}

يتضح من الجدول السابق ما يأتى

لا توجد فروق دالة إحصائية لقيمة (Z) فى الأبعاد و الدرجة الكلية لمقياس

مهار ات التو اصل بين القياسين البعدى و التتبحى للمجموعة التجريبية، وهذا يشير

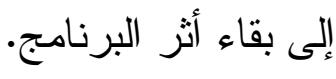
تفسير نتيجة الفرض الثانى :

تشير نتيجة الفرض الثانى إلى " لا توجد فــروق دالــة إحــصائية بــين متوسطات درجات المجموعة التجريبية فى القياس البعدى ومتوسطات درجاتهم فى القياس التتبعى على مقياس مهار ات التواصل 
بعد شهر من انتهاء تطبيق البرنامج "ويشير ذلك إلــى اسـتمر ار آنــار

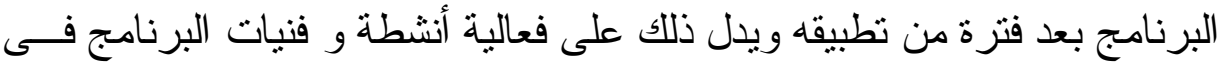

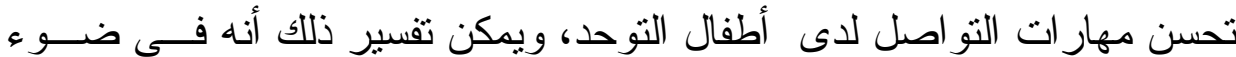
نتائج انشتر الك و انتظام أطفال العينة البحثية فى جلــسات البرنــامج وباســتخدام أنثطة و ألعاب وفنيات منتو عة لتتمية مهار ات التو اصل قد استمرت أنثار ها حتـى

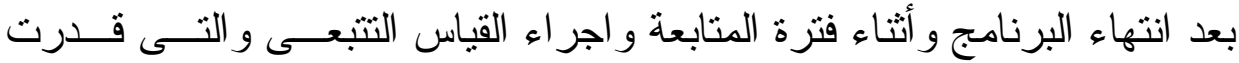
بشهر وبالرجوع الى النتائج الاحصائية الموضحة و المتعلقة بتأثير زمن التطيــق قبليا، بعديا، تتبعيا، لدقياس مهار ات التو اصل نجد أن تلك النتائج الاحصائية التى رئي

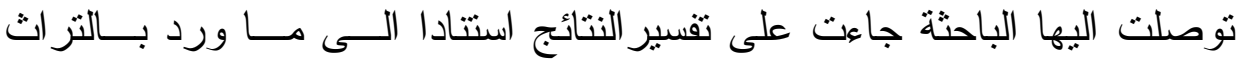

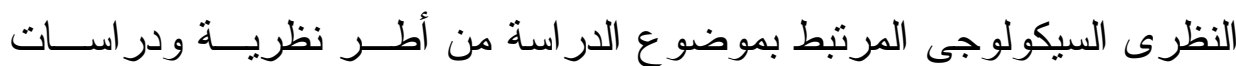

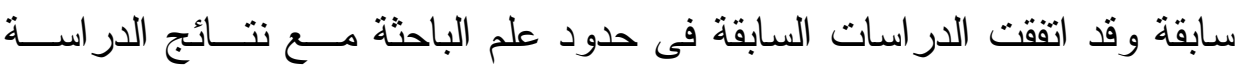

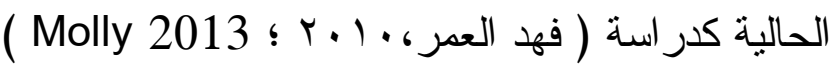
وجاءت أهم توصيات البحث بما يلى ا. ضرورة الابتعاد عن الطرق التقليدية و النمطيــة فـى الطفــل التوحــى المهار ات المختلفة ومحاولة استخدام كل ماهو مستحدث. r. تفعيل دور التكنولوجيا وخاصة البر امج الالكترونية كوسيلة فعالة فى تتمية

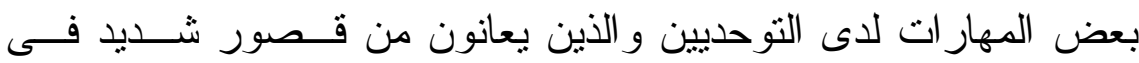

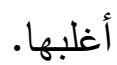
r. لابد من اثر الك الأسرة فى بر امج تدريبية جماعية ومحاولــة تــوجيهمج

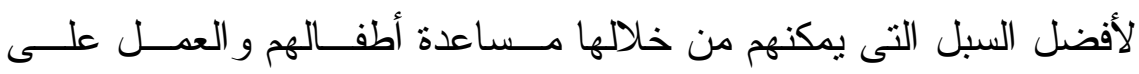

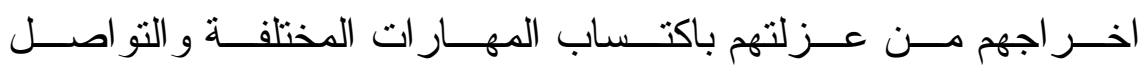

\begin{tabular}{|c|c|}
\hline العدد الأول : يوليو 19+r & rra \\
\hline
\end{tabular}


مع الأخرين مما يساهم فى الحد من العديـــــــن المـشكلات وخاصـــة

$$
\text { السلوكية }
$$

ـ. اجر اء المزيد من الدر اسات و البحوث على نطاق و اســـع و علــى عينــات

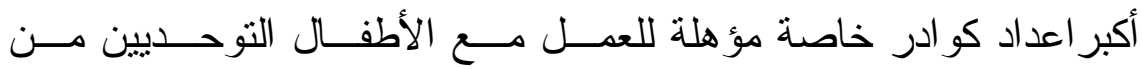

$$
\text { أخصائيين ومدرسين ومدربين. }
$$

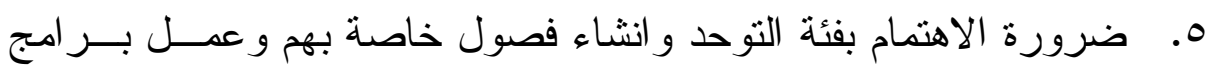

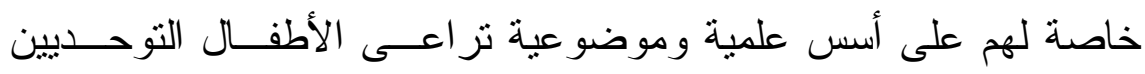
وسماتهم الثخصية المختلفة

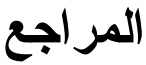

1. ابر اهيم الزريقات، ابر اهيم عبداله فـرج ( • • ب ). التوحـــ الخـصائص

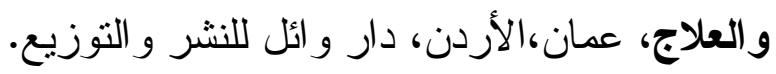

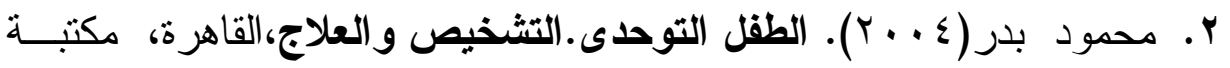

$$
\text { الانجلو المصرية }
$$

r. أسامة مصطفى فاروق (؟ ( ب ). اضطر ابات التواصـل بـين النظريــة

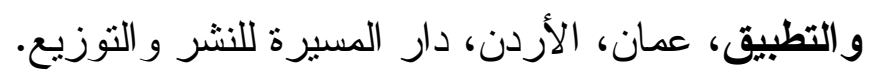

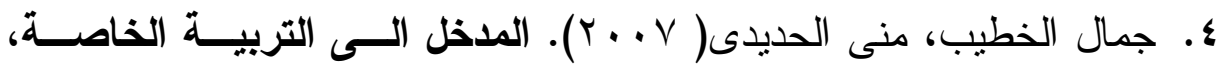
الكويت، مكتبة الفلاح

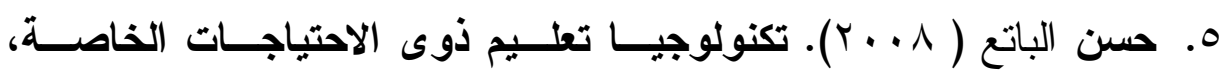
القاهرة، دار الجامعة العة المبن 


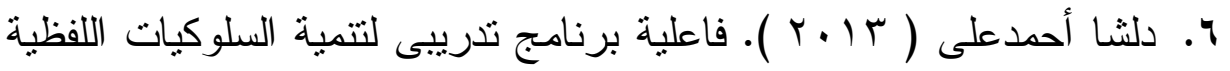

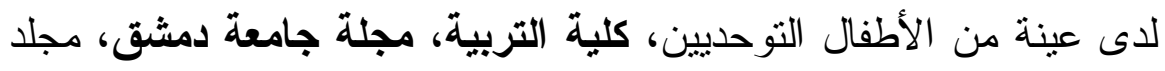

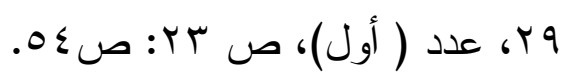

V. زينب شقير ( ( . †). اضطر ابات اللغة والتواصل، القاهرة، مكتبة النهضة

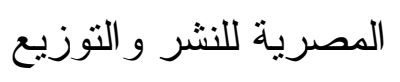

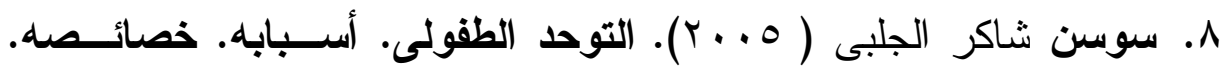

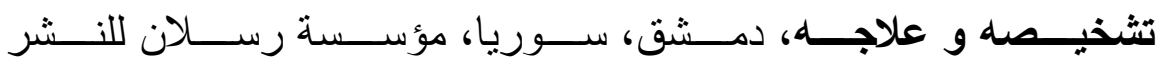

$$
\text { و التوزيع. }
$$

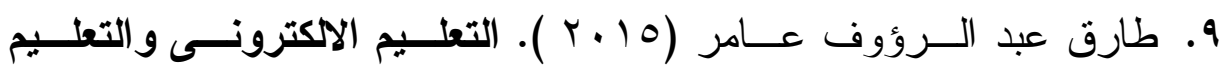

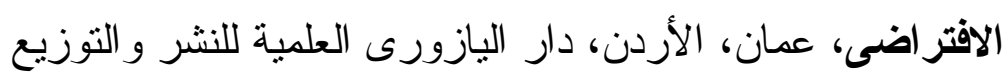

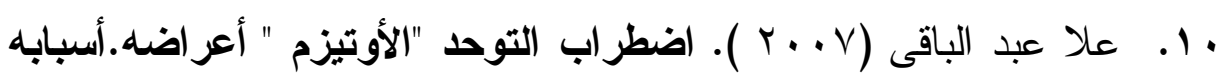

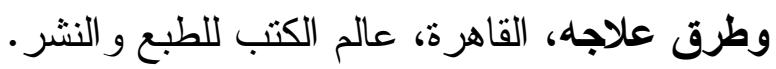

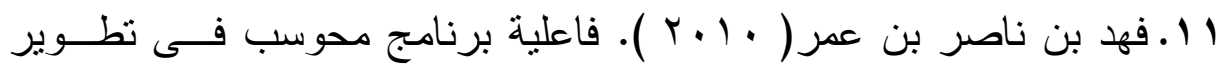

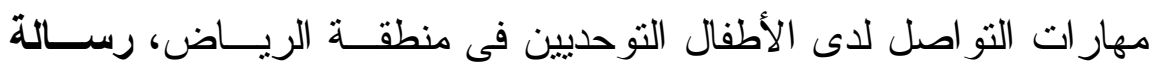
ماجستير غير منشورة،،مكتبة جامعة الأردن.

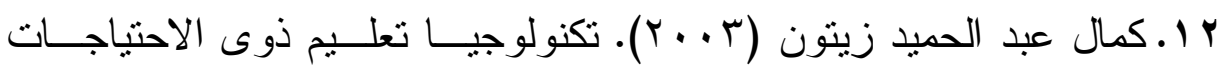

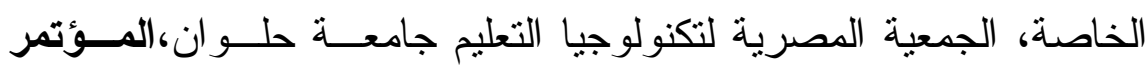

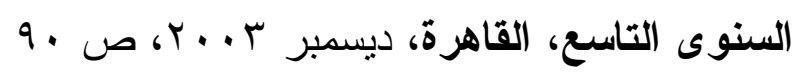

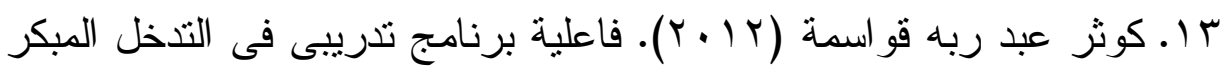

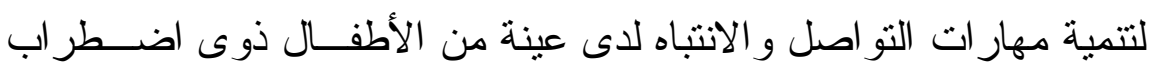
العدد الأول : يوليو 19.
$r \varepsilon$.
المجلد السادس 
التوحد فى الأردن، مجلة كلية التربية "جامعة بنها"، مجلد بrا،عدد( (9)،

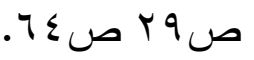

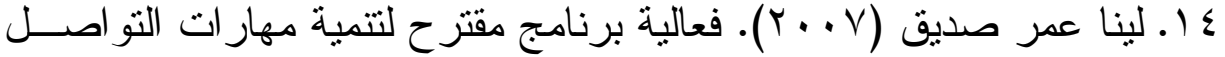

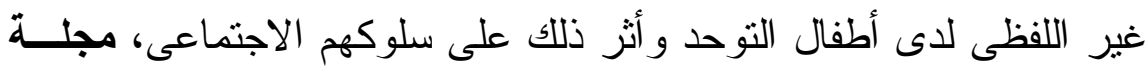

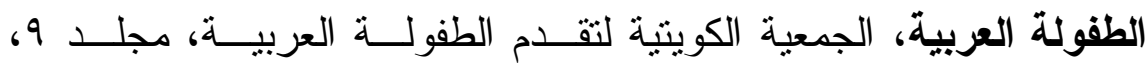

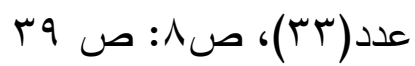

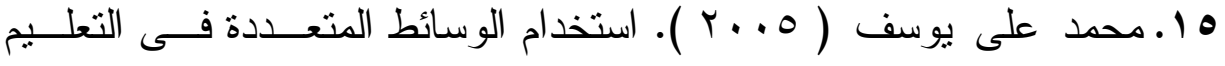
و التذريب، ورشة عمل، المنظمة العربية للتنمية الادارية، جامعة الــدول

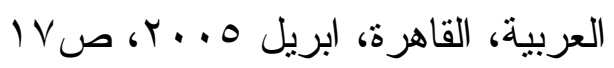

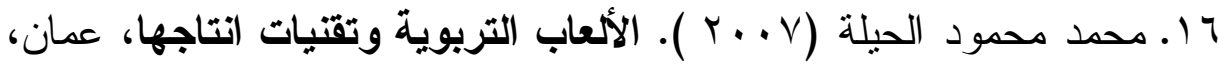

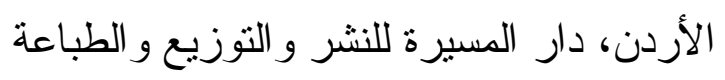

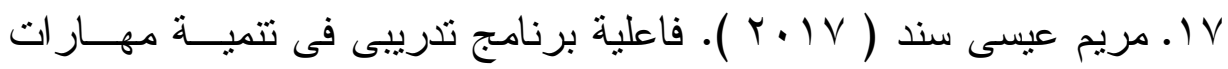
التعبير اللفظى لدى الأطفال ذوى اضطر اب النوحد بدولة الكويت، رسـالة

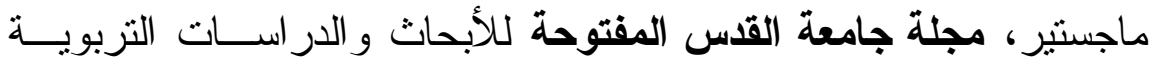

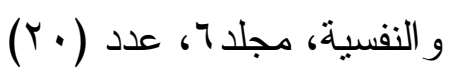

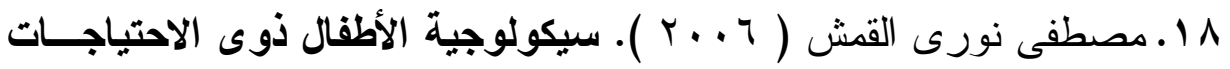

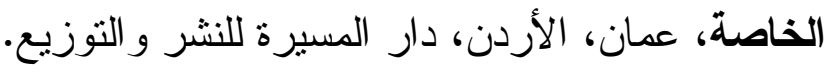

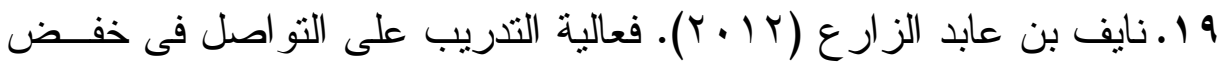

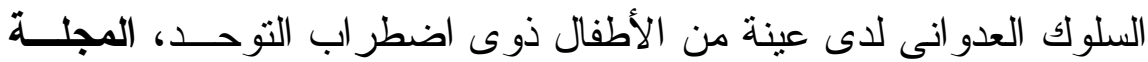


الاولية التزبوية المتخصصة، عمان، الأردن، مجلــــ (، عـدد (0)، ص

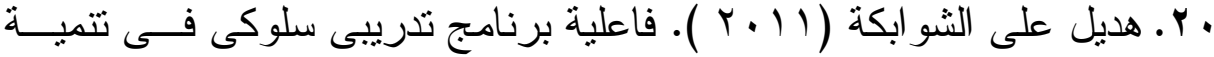

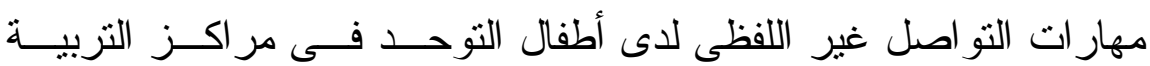

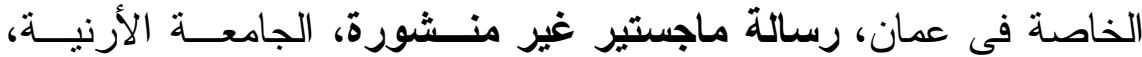

$$
\text { عمان، الأردن. }
$$

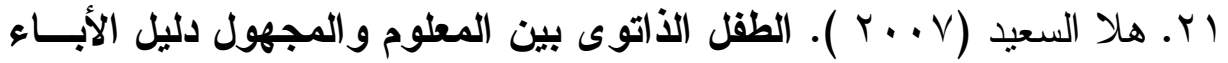
و المتخصصين، القاهرة، مصر، مكتبة الأنجلو المصرية.

r Y. وليد محمد على (10 • ץ). استخدام الاستراتيجيات البصرية فــ تنميــة

مهارات التواصل الاجتماعى لاى الأطفال التوحديين، الأسكندرية، مؤسسة

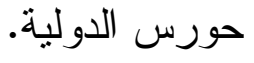

23. Alexis Bosseler, Dominic W. Massoro , $(\uparrow \cdots \varepsilon)$. Developmental \&Evaluation of a computer -Animated Tutor for vocabulary \& language learning in children with Autism, Journal of Autism and Developmental Disorders ,vol.33,No.6 ,434-344.

24. Barbra klipper, (2013) : Apps and Autism tools to serve children with Autism , WWW.American libraries magazine.org

25. Diana Luckevich , (2008). Computer Assisted Instruction for teaching vocabulary to a child with Autism, UMI: No. 3304124.

26. Maggie Mc Gonigle ,Ben Alderson ,(2013). profound expressive language impairment in law functioning

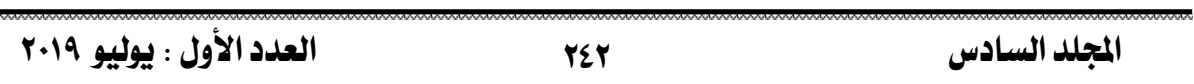


children with Autism, an investigation of syntactic awareness using a computerized learning task, Journal Autism developmental disorder ,43: 2062-2081 Dol 10.1007/s10803-012-1753-Z.

27. Molly Dundon ,T.F Mclaughlin, Jennifer Neyman ,(2013). The effect of a model, lead and test procedure to teach correct requesting using two Apps and Ipad with a 5 year old student with Autism, educational research international ,vol.1, No.3.

28. Monique Moor\& Sandra Calvert,(2000). vocabulary acquisition for children with autism : teacher or computer instruction, Journal of Autism \& developmental disorders, vol :30, No.4,2000.

29. Sally Qzonoff, Gregory S.Young, Alice Carter, Susan Bryson,(2011). Recurrence risk for Autism : A Baby siblings research consortium study, pediatrics.128,e488,

30. Sara L. parmeley (2014). An Exploration of the generalization of conversational social skills for student with autism within a self -contained educational setting ,dissertation submitted to the education faculty of Lindenwood university in partial fulfilment of the requirements for the degree of doctor of education school.

31. Teresa A. cordon, (2016). Technology \& The treatment of children with Autism, Utah valley university oreu.ut. http://www.spring.com

32. Uta firth , (2008). Autism a very short introduction, by Exford university press inc, New York@ uta firth 2008. 
33. Vincent J. carbon \&leigh Obrien \& Emily J. Sweeney Kerwin \&Kristin M. Albert, (2013). Teaching eye contact to children with Autism, Education \& treatment of children , vol.36, No2, 139-159.

34. Michael Farrel,(2006). The effective teachers guide to Autism \& communication ,difficulties, Routledge press, London\& NewYork. 